
ВИКОРИСТАННЯ АВТОРСЬКОЇ КАЗКИ В ПСИХОТЕРАПІЇ ПРИЙНЯТТЯ СЕБЕ
Й НАВКОЛИШНЬОГО СВІТУ НА ПРИКЛАДІ РІЗНИХ ВІКОВИХ ГРУП

\title{
THE USE OF THE AUTHOR'S FAIRY TALE IN PSYCHOTHERAPY OF SELF-ACCEPTANCE AND THE WORLD AROUND US ON THE EXAMPLE OF DIFFERENT AGE GROUPS
}

УДК 316.061.213(477.72)

DOI https://doi.org/10.32843/2663-

5208.2021.26.16

\section{Лазоренко Т.М.}

к.психол.н.,

доцент кафедри теорії

та методики практичної психології

Південноукраїнський національний

педагогічний університет

імені К.Д. Ушинського

\section{Любіченко М.О.}

\section{студентка IV курсу}

за спеціальністю 053 «Психологія»

Південноукраїнський національний педагогічний університет

імені К.Д. Ушинського

\begin{abstract}
У статті розглядається роль авторської казки та їі використання в роботі з клієнтами з метою взаємодії на рівні ціннісного сприйняття власної особистості й переосмислення ситуації та життя загалом. Також приділяється увага транссрормації відносин $з$ оточуючими з менш конструктивних до більш сприятливих для якісного спілкування й розуміння потреб інших. Мета статmі - запропонувати авторські казки для можливості усвідомлення відповідальності за власне життя, звернення до внутрішніх резервів, прийняття себе та несприятливої на перший погляд ситуації, а також проробки й прийняття старості, хвороби і смерті. Треба додати, що метод роботи з казкою спрямовано на несвідомий рівень сприйняття, а також на емоційний рівень, тож переробка інсоормачії, яка вкладена в авторську казку, залежить від конкретних подій, які нині відбуваються в житті окремої людини.

Актуальність створення авторської казки полягає в тому, що в умовах невизначеності, страху хвороби і смерті, як власної, так і рідних, соціальної ізоляції та різкого зменшення контактів, фрінансової невизначеності й невпевненості в собі саме казкотерапія може стати пусковим механізмом до переосмислення особистості та життя в нових умовах. у фокосі статmі - три авторські казки, створені для різних вікових груп (діти, підлітки й дорослі). Нами запропоновано авторські казки для терапії таких ключових життєвих проблем, як відсутність розуміння мотивів поведінки іншого та його особливостей («Горіховий дощ»), невідповідність стандартам і вимогам оточуючих («Жила-була Картина») в стан хвороби, смерті, самотності («У любові без самотності»). Нами створено казки, які б не тільки враховували вікові групи, а й порушували та допомагали трансформувати ключові проблеми, найбільш актуальні саме для цих вікових категорій.
\end{abstract}

Ключові слова: казкотерапія, метод психологічної допомоги, авторська казка, емоції, трансформація, переосмислення.

The article considers the role of the author's fairy tale and its use in working with clients in order to interact at the level of value perception of one's own personality and rethink the situation and life in general. Attention is also paid to the transformation of relationships with others from less constructive to more favorable for quality communication and understanding the needs of others. The purpose of this article is to offer author's tales for the possibility of realizing responsibility for one's own life, turning to internal reserves, accepting oneself and a seemingly unfavorable situation, as well as working out and accepting old age, illness and death. It should be added that the method of working with a fairy tale is aimed at the unconscious level of perception, as well as the emotional level, so the processing of information embedded in the author's tale depends on specific events that currently occur in an individual's life.

The urgency of creating an author's fairy tale is that in conditions of uncertainty, fear of illness and death, both own and family, social isolation and a sharp decrease in contacts, financial uncertainty and self-doubt, fairy tale therapy can be a trigger for rethinking personality and life in new conditions. The focus of the article is three author's fairy tales created for different age groups (children, teenagers and adults). We have proposed author's tales for the treatment of such key life problems as lack of understanding of the motives of another's behavior and its features ("Nut Rain"), inconsistency with the standards and requirements of others ("Once upon a time there was a picture») and illness, death, loneliness («In love without loneliness"). We have created fairy tales that would not only take into account age groups, but also raise and help transform key issues that are most relevant to these age groups.

Key words: fairy tale therapy, method of psychological help, author's fairy tale, emotions, transformation, rethinking.
Використання казки - це своєрідний психологічний інструмент для різних вікових груп, який допомагає більш доцільно взаємодіяти зі світом. Метод роботи з казкою є більш спрямованим на несвідомий рівень сприйняття. Саме підсвідомість запускає потрібну програму в поведінці, яка призводить до трансформації поглядів, цінностей і поведінки [3; 4]. Актуальність створення авторської казки в тому, що в умовах невизначеності, страху хвороби і смерті, як власної, так і рідних, соціальної ізоляції та різкого зменшення контактів, фінансової невизначеності й невпевненості в собі казкотерапія може стати пусковим механізмом до переосмислення особистості й життя в нових умовах.

Ефективність застосування авторської казки в роботі з клієнтами відмічали відомі психологи, як вітчизняні, так і зарубіжні (Е. Берн, Е. Гарднер, Е. Фромм, А. Менегетті, Р. Азовцева, Є. Лисина, М. Осорина, Є. Петрова й інші). Розвитку казкотерапії як самостійному напряму в психології в країнах пострадянського простору сприяли доктор психології, директор Санкт-Петербурзського інституту казкотерапії Т. Зінкевич-Евстигнєєва, яка запропонувала систему «казкотерапевтичної психокорекції», доктор педагогічних наук 
Т. Грабенко, психотерапевт Д. Соколов, доктор медичних наук А. Гнезділов, відомий як Доктор Балу [5, с. 9]. Так, серед функцій психотерапевтичних казок А. Гнезділов виділяє згладжування опору клієнта, актуалізацію подій, що є витисненими, заповнення прогалин індивідуальної історії клієнта та її доповнення, відображення внутрішнього конфлікту, демонстрацію альтернативи сприйняття неоднозначних життєвих подій, формування конструктивної поведінки та нового погляду на ситуацію, нарешті, психотерапевтична казка формує віру в позитивне вирішення проблеми [1, с. 8-9]. Психотерапевт Д. Соколов підкреслює, що казка впливає також і на самого психотерапевта тим, що не тільки пробуджує його творчі сили, а й допомагає розуміти ситуацію клієнта на інтуїтивному рівні, тобто на рівні архетипів і першого враження [3].

У роботі ми намагалися створити авторські психотерапевтичні казки для трьох вікових категорій (діти, підлітки та дорослі), які б не тільки враховували вікові групи, а й порушували та допомагали трансформувати ключові життєві проблеми, найбільш актуальні саме для цих вікових категорій: відсутність розуміння мотивів поведінки іншого та його особливостей, невідповідність стандартам і вимогам оточуючих, стан хвороби, смерті й самотності.

Загального поняття «казкотерапія» не існує, але вирізняють такі:

- це лікування казками, спільне відкриття знань, що живуть у душі та $є$ нині психотерапевтичними;

- це процес пошуку сенсу, розкодування знань про світ і систему взаємовідносин у ньому;

- це процес створення зв'язку між подіями казки та поведінкою в реальності, тобто перенесення казкових смислів до справжнього життя;

- це процес об'єктивізації проблемних ситуацій, активізації ресурсів та потенціалу особистості;

- це терапія казковим середовищем, у якому з'являється нереалізована частина особистості та почуття захищеності й таємничості [5, с. 8].

Основа психологічної проблеми, як підкреслює психотерапевт Д. Соколов, - це незавершеність, тобто людина зупиняється перед тим, що її лякає, і багаторазово повертається до ії початку, доходить майже до кульмінації та зупиняється, витісняє та "вистрибує» із ситуації [3]. Якщо ж цю жахливу для клієнта подію пережити, настане гарна кінцівка. Казкотерапія, яка дуже вдало працює саме з несвідомою, витисненою частиною свідомості, допомагає в цьому процесі.

Казкотерапія як напрям практичної психології порівняно з іншими підходами має неба- гато обмежень: вона працює з різними віковими категоріями, з різними людьми, у тому числі з відхиленнями в розвитку, охоплює різні види життєвих проблем [1, с. 7]. Психотерапевт А. Гнезділов підкреслює, що сучасна казкотерапія має три функції - діагностичну, впливову та профілактичну [1, с. 7]. Що стосується метода під назвою «казкотерапія», то він спрямований на розуміння різних стилів світосприйняття, осмисленої позитивної взаємодії зі світом, розуміння причинно-наслідкових зв'язків та усвідомлення власного потенціалу й можливостей індивіда, а також цінності власного життя та внутрішнє відчуття сили й гармонії $[1$, с. 8-9]. Саме в казках дитина знаходить моделі поведінки, знайомиться з такими поняттями, як добро і зло, розуміє стан речей і закономірності взаємовідносин і подій. Щоб казка допомогла та зробила психотерапевтичний чи психокорекційний вплив на дитину, необхідно дотримуватися певних правил ії створення:

- казка має бути зі схожою проблемою, але не прямо відображати їі;

- казка має пропонувати альтернативний досвід, який дитина змогла б трансформувати й «побачити» можливості нового вибору;

- казковий сюжет має розгортатися в певній послідовності:

1) жили-були;

2) раптом одного разу...

3) у зв'язку з цим

4) кульмінація

5) розв'язка

6) мораль $[4$, с. 8-9].

Підліткам і дорослим казкотерапія в емоційному аспекті $€$ ключем до особистісного ресурсу, переосмислення життєвих подій, вчинків і життя загалом $[1 ; 2]$.

Авторські психотерапевтичні казки

Проблема: відсутність розуміння мотивів поведінки іншого та його особливостей.

Задача: психотерапевтична (проробка травмувальної ситуації), корекційна (модель нової поведінки, навичок будувати відносини, розвиток емпатії).

Завдання: виховувати здатність відчувати і сприймати інших; навчити дитину бути в гармонії з собою та оточуючими.

Вікова категорія: діти старшого дошкільного, молодшого й середнього шкільного віку.

Горіховий дощ

Я знаю, що таке горіховий дощ. Ось я зараз вимовляю цю назву - і одразу ж відчуваю, як простір навколо мене наповнюється трохи гіркуватим запахом молодих горіхів, ще вкритих м'якою зеленою шкіркою і зовсім маленьких. O, яким непередбачуваним є цей таємничий дощ - ніколи не знаєш, коли він почнеться й коли перестане йти. Одне правильно: його потоки обрушуються на тебе не просто 
раптово, а саме в той час, коли ти найменше цього очікуєш. Так сталося одного разу з одним зайченям, якого звали Промінчик.

Був найчудовіший, чарівний, прекрасний (мій друже, обери найкраще слово) день. Сонечко світило так ніжно, хмари були такими білими, а вода в потічку такою прохолодною, що хотілося поділитися своїм гарним настроєм з усіма, тому зайченя Промінчик радісно вітав кожного, хто траплявся йому на шляху, - від крихітного жучка до бурої ведмедиці. Промінчик збирав свої улюблені волошки, щоб потім прикрасити фортеці з річкового піску, які він так любив будувати. Погода сприяла цьому милому заняттю, тому, наспівуючи якийсь веселий мотив собі під ніс, малюк попрямував у бік струмка й дуже скоро почув плюскіт води. Тут народжувався струмочок. Зайченя трохи поспостерігав за фонтаном з бризок, які скакали наввипередки, а потім побрів уздовж течії в пошуках найкращого містечка для зведення своїх тендітних фортець.

Промінчик ішов недовго: на потрібний майданчик він натрапив абсолютно випадково, коли обходив якийсь чагарник, що виріс усього в декількох кроках біля струмка, який, утім, уже перетворився на справжню повноводну річку. Зайченя озирнувся - навколо не було анікого, тільки весело плескалися у воді рибки та дзвінко щебетали й пурхали солодкоголосі птиці. Малюк зупинився, обережно поклав букет із волошок трохи віддалік, щоб квіти ненароком не підхопив плин, і підійшов до самої кромки води, потім сів навпочіпки й зачерпнув лапкою жменю мокрого річкового піску. Так з'явився перший тендітний фундамент. Потім Промінчик зачерпнув піску ще і ще - майбутня фортеця стала зовсім невисоко підніматися над землею. Зайченя захопився - він творив, він зводив, він створював химерні неймовірні чарівні візерунки з мокрого піску, які з'єднувалися в башточки, перетворюючись у казкові фортеці.

Важко сказати, скільки минуло часу перед тим, як Промінчик зупинився, розім'яв трохи затерплі від одноманітної пози плечі й озирнувся. Навколо відбулися помітні зміни: сонце сховалося в небі, наче його не було зовсім, ніби не його промені лоскотали ніс зайченяті ще кілька годин тому, птиці стихли й, мабуть, сховалися; вода в зазвичай спокійній річці стала лютою і вируючою. Промінчик підняв голову вгору і побачив, що разючі зміни відбулися й у небі: замість ніжних пухнастих хмаринок, по ньому металися сизі хмари. Малюк перевів погляд на свої тендітні фортеці вони були такими гарними, такими рідними, і такими беззахисними, із синіми волошками, що прикрашали верхівки башточок. Промінчик так і застиг з останньою волошкою в руці, найяскравішою та найгарнішою, її він зби- рався розташувати на найпочеснішому місці в центрі. І раптом він відчув, що свіже повітря навколо нього наповнилося трохи гіркуватим запахом молодих горіхів, тих, зовсім маленьких, ще вкритих ніжною зеленою шкіркою. Цей аромат лякав зайченя й разом із тим вабив кудись, малюючи розмиті картини минулого, зовсім забуті, як здавалося Промінчику.

І ось він ринув, він обрушився на розгубленого зайченя, цей непередбачуваний горіховий дощ. Він лоскотав йому ніс і вуха, він змушував жмуритися й моргати, але головне - він, здавалося, проникав в саме серце і змушував його сумно стискатися. Промінчик стояв під проливним горіховим дощем і навіть не думав тікати або кудись ховатися. Навіщо - адже на його очах з блискавичною швидкістю танули його фортеці з річкового піску. Ось обвалилися найгостріші піки, ось, у мить ока, високі стрункі башточки стали низькими та широкими, а сині волошки розгублено лежали поряд на піску. Ще секунда - й остання вежа повалена, потоки дощу підхопили брудні сині квіти і стрімко понесли до річки, яка несла їх усе далі. Промінчик стояв і плакав - його сльози змішувалися з горіховими краплями й падали, падали... Йому, безумовно, було шкода фортець, але було щось ще, щось незрозуміле. Він відчував, що йому сумно-сумно, і виною цьому безрадісному стану $є$ горіховий дощ, який так раптово увірвався в чудовий сонячний день. Зайченя щосили стиснув кулачки: «Проклятий дощ!» - закричав Промінчик, - «Ти зіпсував усе! Мої пісочні фортеці! Я так старався! Навіщо?» Зайченя відчував, що він $є$ дуже розлюченим, і чим більше він сердився, тим більше в його пам'яті починала проступати знайома картинка. O, скільки разів він намагався загнати її глибоко всередину, щоб не згадувати. Зайченяті здавалося, що йому вдалося забути... але на жаль.

Промінчик відчув, що струмені горіхового дощу відірвали його від землі, підняли над землею і понесли кудись. Навколо - тільки стіни води. Але ось, нарешті, малюк відчув тепло землі, дощ відступив, як ніби його й не було зовсім. Промінчик подивився на всі боки й жахнувся: те, чого він не хотів згадувати найбільше всього на світі, відбувалося з ним знову. Він ішов по дорозі з величезним букетом квітів. Це був абсолютно чудовий букет: ромашки привітно махали своїми білими пелюсточками, маки гордо червоніли на тлі цих блідих сусідок; тут були фіолетові дзвіночки й маленькі жовті квіточки, назви яких Промінчик не міг згадати. I, звичайно, серед інших квітів виділялися його улюблені небесно-сині волошки. Він радісно ніс букет для матусі. I треба ж такому статися, що саме в цей момент назустріч вибігло слоненя, відомий товстун і задирака. «Так-так-так, - примружилося слоненя, - і куди це ти прямуєш?» Промінчик відступив назад, ховаючи свій величезний букет за спиною. «О, тут у нас квіточки! 
А ну покажи!» Звичайно, зайченя не поспішало продемонструвати свій букет, а слоненяті кортіло подивитися на квіти ближче, тому кожен став тягнути його до себе. Дуже скоро на землю почали падати різнокольорові пелюстки - і червоні, і білі, і жовті, і сині. Від самого букета залишилися тільки зелені стеблини, неабияк пом'яті й подекуди поламані. Промінчик стояв і плакав, слоненя поспішило сховатися. І, дивлячись на те, що залишилося від квітів, зайченя, нарешті, кинуло стеблинки на траву, як раптом побачив, що серед зелені промайнуло щось синє. Виявилося, що це була єдина квітка, що зберіглася після неприємної зустрічі, - його улюблена волошка. Тоді Промінчик підняв їі. Квітка була досить великою та дуже красивою. Цю останню волошку малюк і вручив своїй улюбленій матусі. І нічого їй не розповів. Але почуття образи й роздратування залишилося з ним, десь глибоко. Ось яку історію Промінчик безуспішно намагався забути. Ось у який відрізок життя переніс його загадковий горіховий дощ.

Не встигло зайченя змахнути останню сльозу, як знову відчув аромат гірких молодих горіхів, і в цю ж мить струмені дощу підняли його над землею, змиваючи сльози й лоскочачи ніс і вуха. Й ось зайченя знову відчуло щось тверде під ногами. Воно опинилося в кімнаті слоненяти, але той його чомусь не бачив. Промінчик хотів ударити його або хоча б штовхнути, але не зміг: слоненя було ніби в серпанку. До кімнати ввійшла мама-слониха. Вона підійшла до свого сина й обняла його. І раптом Промінчик побачив, що слоненя плаче. «Не плач, малюк. Ми тебе дуже любимо», - сказала слониха й погладила синочка по голові. «Так, але більше мене не любить ніхто, зі мною не хочуть грати, у мене немає друзів. Напевно, тому що я - товстий, і вуха в мене великі, і хобот - он який». І слоненя заридало ще більше. «Та ні, мій милий, ти ж слон, а слони всі саме такі», - і слониха-мама почала його жаліти. «А сьогодні я хотів познайомитися із симпатичним зайченям. Я знаю, що його звуть Промінчик, - продовжувало, ковтаючи сльози, слоненя, - але він теж не захотів зі мною спілкуватися, а я довго шукати привід для знайомства й, нарешті, знайшов. А вийшло зовсім погано», - $з$ величезних сумних очей слоненяти не переставали литися сльози. Що відбувалося далі, Промінчик не бачив, приголомшений почутим: горіховий дощ раптово підхопив його й досить довго кружляв з ним у повітрі. Нарешті, зайченя почуло плюскіт знайомої річки та відчуло мокрий пісок під ногами.

Промінчик відкрив очі. Погода була чудовою: сонце підморгувало, пташки змагалися у вишуканості трелей, річка текла спокійно, відображаючи блакитне небо з м'якими пухнастими хмаринками. Але головне - фортеці, його фортеці з річкового піску, прикрашені волошками, були неушкодженими. Зайченя заплющило очі, хитнув головою, розплющив усе, як раніше. Ніби й не було цього горіхового дощу, що раптово ввірвався своїми потоками в сонячний день. Промінчик на хвилинку замислився, потім раптом зірвався з місця й побіг, стискаючи останню волошку, яка повинна була зайняти найпочесніше місце у самому центрі головної фортеці.

Промінчик біг і біг, поки, нарешті, не побачив будиночок, у якому жило слоненя. Зайченя нетерпляче подзвонило у дзвінок, про всяк випадок постукало в двері та знову подзвонило. На порозі з'явився розгублений слоник, якого до сьогоднішнього дня Промінчик уважав задиракою. Зайченя простягнуло йому лапку і сказало: «я - Промінчик, ти, звичайно, це знаєш, але ж ми так і не познайомилися. Я хотів вибачитися за той випадок, коли я не показав тобі букет, - швидко вигукнуло зайченя й додало: А я навіть не знаю, як тебе звати». «Я - Тобік, зніяковіло відповіло слоненя, - я радий, що ти прийшов, але я думав, що ти не захочеш зі мною спілкуватися, адже я тоді порвав твій букет». «Це тому, що я поскупився», - посміхнувся Промінчик. «Я, до речі, прийшов запросити тебе подивитися на мої пісочні фортеці. Ти підеш?» «Звичайно», - зрадів Тобік. І вже зовсім скоро Промінчик показував новому другові казкові тендітні фортеці, прикрашені синіми квітами. Слоненя застило в захопленні. «я не зможу так, - зітхнув він, - адже я такий неповороткий». «Ти - слоненя, усі слони великі, але це не означає, що вони неповороткі! Я обов'язково навчу тебе, і ми будемо будувати фортеці з річкового піску разом! А поки в мене є для тебе особливе доручення» - і Промінчик простягнув Тобікові волошку. Слоненя дуже старанно прикрасило квіткою найпочесніше місце химерної пісочної композиції.

Вони побудували багато красивих фортець, зайченя і слоник. Вони все робили разом, адже вони були справжніми друзями. Іноді Промінчикові здавалося, що в повітрі пахне гіркими молодими горіхами. Він чекав, що почнеться горіховий дощ, так що так дивно змінив його долю. Але дощ не починався, замість цього, мама-зайчиха витягувала з духовки апетитний горіховий пиріг, який так подобався слоненяті.

Проблема: невідповідність стандартам і вимогам оточуючих.

Задача: психотерапевтична (проробка травмувальної ситуації), корекційна (сприйняття себе, самоідентифікація).

Завдання: зробити самооцінку стабільною; навчити сприймати критику; навчити бути в гармонії із собою; розуміння своєї ролі та місця в житті.

Вікова категорія: підлітки, юнаки. Жила-була Картина.

Жила-була Картина. Вона була зовсім юною - її створив молодий художник, він уклав 
у неї всю душу й увесь талант; можливо, йому не вистачало досвіду, але, безсумнівно, його творіння вийшло гармонійним, яскравим і свіжим. Картина носила так званий почерк свого творця: у ній було щось легке й неповторне, трохи наївне, але справжнє. Художник розташував творіння на найкращому місці його маленької квартирки. А одного разу він примудрився зібрати грошей на красиву раму, що так чудово відтіняла ії. Картині було приємно, що про неї піклуються, вона любила свого творця, їй подобалося спостерігати за тим, з яким запалом і трепетом, 3 якою серйозністю та благоговінням він створює свої нові роботи. Картина була цілком щаслива, але в неї була одна мрія. Точніше, Мрія з великої літери: вона хотіла стати справжнім Шедевром. Вона бачила, як молодий художник розглядав репродукції великих майстрів, чиї картини по праву вважалися шедеврами. Шедеври були вельми шанобливого віку, горді та небагатослівні. «Їх поважають, ними захоплюються!»вигукувала дивлячись на них Картина. «Вони чудові, але я теж, я теж хочу подобається всім!» І вона мріяла, мріяла, мріяла...

Картина була посередньою - і молодий художник це розумів, але він любив ії̈, одну зі своїх перших серйозних робіт. Йому подобався пейзаж, зображений на ній, він згадував, як довго він відшукував цей чудовий куточок, цей «оазис щастя», як він його називав, але виявилося, що такого місця не існувало - і творцеві довелося самому його створити. Одного разу художник прийшов додому дуже жвавий і веселий. Він снував туди-сюди, переглядаючи картини. Потім він складав їх, дбайливо обернувши тканиною, та, нарешті, втомлений і задоволений, він опустився на край дивана. Йому належало організувати свою першу персональну виставку. Він дивився на Картину, яка висіла прямо перед ним, і ніби відчував легкий вітерець, що приносить свіжий запах моря, бачив, як далеко колишуться маленькі хвилі, як лижуть піщаний берег баранці, немов чув крики чайок, що вільно пурхають високо-високо, немов удихав аромат дивовижних рослин, що привертали увагу своєю рідкісною красою, а промені втомленого, але радісного рожево-червоного сонця ніби торкалися його обличчя, плечей, зігріваючи та даруючи спокій і надію. Юний художник посміхнувся, похитав головою, розсіюючи приємну напівдрімоту, устав і підійшов до Картини. Він ще раз посміхнувся думці про те, що, нарешті, виконає ії мрію і покаже ії іншим. Він трепетно зняв ії̈ зі стіни й загорнув у м'яку оксамитову тканину.

Коли Картина, яка мріяла стати Шедевром, нарешті розплющила очі, вона здивовано побачила, що знаходиться в красивому освітленому залі. На сусідніх стінах теж висять картини - роботи її творця. I все ж вона, безу- мовно, була розташована на найкращому, на найвигіднішому місці. Картина посміхнулася: «Нарешті мене все побачать, будуть стояти та розглядати, i, звичайно, я їм сподобаюся!» Залишилося зовсім небагато часу до відкриття першої персональної виставки молодого художника - вона це відчувала, та її серце тріпотіло від хвилювання й нетерпіння.

Легка приємна музика, шум голосів, що зливаються зі скрипом паркету й вигуками вітання та поздоровлення; багато осіб, зовсім різних - гордовитих, веселих, суворих, замислених, байдужих. Байдужих... Картина зіщулилася, настільки холодними виявилися ці особи, чомусь їх було досить багато, вони ії дуже бентежили. Але ось у гулі голосів Картина почала розрізняти окремі слова. «Посередня», - почула вона зліва від себе й, обернувшись на суворий голос, побачила худу статну даму з лорнетом. I, о жах, лорнет був спрямований на неї. «Примітивна», - вторив ій низький глухий голос, володар якого, невисокий пан з рудими вусами, скривився й, ковзнувши по Картині колючим поглядом, повернувся до неї спиною. «Посередня. Примітивна. Посередня. Примітивна. Примітивна. Примітивна», - Картина вже не розуміла, чи чує вона насправді ці жахливі вигуки, що жалять серце, або вони проникли в її свідомість, щоб тепер мучити та знищувати її, але їй було дуже погано. Кожне таке слово, яке звучало, немов відлуння, у її голові, відколювало шматочок іiї кришталевої Мрії та нещадно розбивало цю чарівну тендітну мрію. Як багато було цих уламків, кожен із них боляче ранив Картину, хоча цього ніхто не бачив.

«Ти, напевно, дуже втомилася, але вже настав ранок, такий гарний, що його треба побачити», - ніжно прошепотів молодий художник, і Картина прокинулася. Уже не було задушливих стін красивого залу, замість цього - мольберт, на якому вона стояла, поряд - ії творець із палітрою в руках і з чистим полотном перед ним, а навколо - зелень молодої трави й дерев і приємний запах маленьких диких квіточок, а небо над ними - таке синє, зовсім безхмарне й дуже приємні теплі промені сонця. «Я знав, що тобі сподобається, посміхнувся художник, - мені здалося, що сьогодні - особливий день, і я вирішив створити щось нове. А без мого улюбленого «оази щастя», тебе, мені важче творити». Картина посміхнулася, а художник зробив перший мазок. «І, до речі, я помітив, що вчора ти дуже засмутилася. Напевно, тобі було занадто душно та дуже шумно, а ти в мене - ніжна і вразлива. Я вирішив забрати тебе із собою нехай дивляться на інші картини й кидають свої колючі фрази на їхню адресу, але ж ти аж ніяк не примітивна або посередня. Напевно, для них, може, навіть для більшості ти - далеко 
не шедевр, але тільки не для мене! Навіть не тому що ти - моє дітище; ти - унікальна, неповторна, ти - особлива, а отже, ти є справжнім Шедевром!» Картина довго не могла прийти до тями від радості та здивування. Як їй раніше на думку не спадало, що всім подобається неможливо - не можна бути хорошою для всіх. Але ж можна бути найкращою для обраних, для значущих та улюблених.

Сонечко вже почало хилитися до землі, фарбуючи горизонт рожевим кольором і захоплюючи душу своєю величністю. I саме в цей момент Картина відчула неймовірну радість, їй здалося, що її розкішна рама, дбайливо підібрана її творцем, стала занадто тісною для неї через натовп почуття, яке буквально переповнювало її. I вона не змогла втриматися - вона вийшла за рамки, вона немов стала набагато ширша та глибша. Картина ясно відчула себе справжнім Шедевром, вільним від наносного лушпиння пафосу й суб'єктивних оцінок, від бажання бути визнаною і здаватися досконалою. Вона відчула, що в цей момент стала собою, справжньою та вільною. Вона ожила. А художник захоплено дивився на неї - її полотно, обрамлене рамою, було порожнім, натомість перед творцем відкрився чудовий краєвид. Він відчував легкий вітерець, що приносить свіжий запах моря, бачив, як далеко колишуться маленькі хвилі, як лижуть піщаний берег баранці, чув крики чайок, що вільно пурхають високо-високо, вдихав аромат дивовижних рослин, що привертають увагу своєю рідкісною красою. Це було так чудово! Молодий художник знайшов свій справжній «оазис щастя». У цей самий час промені сонця, що майже зайшло за горизонт, торкнулися його обличчя та плечей, немов огортаючи його хвилею тепла і щастя ...

До речі, за свою Картину художник згодом отримав всесвітнє визнання. Ї̈̈ оголосили справжнім Шедевром. Але ані творцеві, ані його творінню це було неважливо. А на питання, де ж тепер його Картина-Шедевр, молодий художник мудро посміхався.

Проблема: страх старості, хвороби, смерті й самотності.

Задача: психотерапевтична (прийняття й проробка травмувальної ситуації).

Завдання: екзистенційне осмислення народження, життя, старості, смерті й самотності.

\section{Вікова категорія: дорослі.}

\section{у любові без самотності}

Це - сумна казка, мій друже. Вона не для того, щоб потішити тебе або зміцнити сили та віру в себе. Вона - про два найбільш хвилюючі й таємничі моменти життя, без яких, власне, неможливе саме життя. Моя казка - про народження та смерть, ці прямо протилежні процеси, немов схід і захід...
У горобиній родині було шумно. Горобець помітно нервував і снував туди-сюди, сюдитуди і знову туди-сюди, сюди-туди. Він давно чекав цього моменту, й ось тепер не міг знайти собі місця від хвилювання. А хвилювання було неабияким - у його коханої дружини ось-ось повинен був з'явитися первісток. До ролі тата Горобець підготувався добре: він вибрав найкраще місце для нового житла, так, щоб неподалік їжі було вдосталь і поряд із цим щоб жодна кішка не змогла знайти сюди дорогу. Він упорядкував гніздо, яке стало дуже затишним, тобто таким, як потрібно для його молодої родини та їхнього майбутнього малюка. Горобець уже кілька разів усе перевірив, неодноразово почистив своє блискуче пір'ячко й тепер в очкуванні не знаходив собі місця. А між тим було ще досить темно, досвітній час обіцяв подарувати відмінний весняний день, але поки що цю обіцянку не підкріплював жоден, навіть малесенький промінчик сонця. Усі інші птахи спали, хоча на ще закритих квітках уже з'явилася ранкова роса, ніжно брязкаючи маленькими крапельками; це туман важливо клубочився по землі, насичуючи її своєю прохолодною вологою. Й ось через півгодини радісний світанок розфарбував ранкове весняне небо. Як тільки перший ранній веселий сонячний промінь торкнувся землі, на розкидистому високому дереві в затишному гнізді на світ з'явився довгоочікуваний малюк Горобець став татом, а його кохана дружина Горобчиха - мамою.

Вони були дуже непосидючими, ці молоді батьки, напевно, вони робили багато помилок - і у своєму житті, і у вихованні синочка; їм, безумовно, не вистачало досвіду, але ні в якому разі не любові - цим теплим трепетним почуттям їхні маленькі горобині сердечка були пронизані сповна. Малюк запам'ятав чудовий день свого народження, точніше, пам'ятав він його смутно, але це всеосяжне відчуття любові, підтримки та щирої радості батьків він зберіг у найбільш ніжному та затишному куточку свого серця. Потім не раз, у хвилини туги й негоди, це світле почуття раптово виривалося назовні, заповнюючи порожнечу та розсіюючи тривогу...

Горобець розплющив очі. Він укотре згадував своїх батьків і день, у який він з'явився на світ, - із першими світанковими променями. Навряд чи хто-небудь впізнав би в цьому ставному, незважаючи на невеликий зріст, птаху того малюка. Горобець уже встиг прожити великий відрізок свого життя, він і будинок, як годиться, побудував, і привів у нього господиню - чарівну Горобчиху, i, звичайно, у них були гарненькі дітки - веселі та кмітливі. Утім тепер вони вже досить підросли для того, щоб самим замислюватися про свої власні гнізда. Власне, ця обставина й турбувала Горобця, 
який розумів, що ще трохи - і діти покинуть батьківський будинок. Проте він так звик чути їхн веселе щебетання вранці та із задоволенням розповідати їм дивовижні казки на ніч. Але Горобець був мудрим, тому він відпустив кожне своє чадо в нове самостійне життя, як тільки прийшов час. Він боявся цього щемливого відчуття самотності, яке лоскотало його пір'я під самою грудкою, але й воно відступило, поступившись місцем радісному очікуванню тих днів, коли вся родина, що стала ще більшою, збиралася разом. Крім того, виявилося, що й у спорожнілому гнізді не так сумно: у Горобця та його чудової дружини немов почалася друга хвиля закоханості. Горобець, як і в минулі часи, чепурився і кликав ії на побачення на старий дах; а його кохана молоділа та гарнішала на очах. Навіть коли вони стали дідусем і бабусею.

Горобець любив удаватися до спогадів. Бувало всядеться він у старе крісло-гойдалку, укутається в теплу ковдру, візьме улюблену книжку та зануриться в спогади. Згадає своїх улюблених батьків, дитячі пустощі, перше кохання й обов'язково мрійливо запитає в Горобчихи: «А пам'ятаєш, люба, як ми познайомилися!» У такі моменти Горобчиха відкидала своє в'язання, зніяковіло поправляла окуляри та посміхалася. I вони заново переживали всю гаму почуттів, переносячись, немов за помахом чарівної палички, до часів своєї молодості. Ось і зараз на вулиці накрапував дощ, пожовклі дерева стояли мокрі та похмурі, а в горобиному гніздечку було затишно й тепло. Горобець завернувся до спогадів, а Горобчиха дивилася на нього й усміхалася. Саме в цю щасливу мить у їхній будинок постукала старість. Ї̈̈ присутність відчув Горобець, у якого кольнуло в грудях і перехопило подих. На схвильоване питання дружини, він відповів, що, імовірно, просто трішки втомився. Вона турбувалася, але чоловік був настільки радіснім і веселим, що пильність і занепокоєння Горобчихи мало-помалу вляглися.

Осінь була в самому розпалі. Стало досить холодно, але сонячні промені все ще дарували своє світло й хоч якесь тепло землі, що поступово занурювалася в сон. Горобець із Горобчихою повільно прогулювалися по завмерлих алеях, як у дитинстві, штовхаючи ногами жовте листя, яке весело шаруділо у відповідь. Тепло сердець і ніжність почуттів подружжя з лишком заповнювали недолік сонячного тепла навіть найсумніший дощовий день. Утім їм він не здавався похмурим: крапельки дощу, барабанячи по великий парасолі, дарували незвичайні мелодії - то ритмічні, дзвінкі, то спокійні задумливі. Горобець навіть не припускав, що зрілість може бути такою величною. Коли він був ще зовсім молодим, то розумів, що дитинство - веселе й безтурботне, юність - чарівна, але старість тоді здавалася йому чимось до болю неприємним і непотрібним, вона пригнічувала його своєю неминучістю. Але, на диво, осінь його життя виявилася ласкавою і світлою, набагато глибшою, ніж літо, зі щемливими відгомонами весни.

Одного разу, коли Горобець і Горобчиха вийшли на прогулянку, вони відчули, що повітря стало морозним і свіжим; на калюжках з'явилася тоненька, ледь помітна скоринка льоду, а останній засохлий лист покинув дерево й тепер повільно кружляв, немов прощаючись з осінню та поступаючись дорогою зимі. А Зима не змусила себе довго чекати. Уже наступного дня гордою ходою, неквапливо вона ступила на заснулу землю, оглянула сплячі дерева та привітала застигле біле сонце. Сонце випустило їй назустріч кілька обережних невагомих промінчиків. Один із них сковзнув по дереву, на якому жили Горобець із Горобчихою, зупинився, заглянув у вікно їхнього затишного маленького житла. Горобець прокинувся. Його кохана ще спала, він ніжно поцілував ії і подивився у вікно. Там, на вулиці, виразно відчувалася присутність Зими, незважаючи на те що снігу ще не було. Горобець налив собі солодкого полуничного чаю і замислився. У цю ніч він спав неспокійно, чомусь його груди переповнювала туга, а серце калатало трохи злякано. Це було дивно, адже саме сьогодні до них у гості повинні прилетіти улюблені діти та рідні внуки, тобто день обіцяв бути радісним і хвилюючим. Утім, як тільки в гніздечку пролунали веселі голоси перших гостей, тривога вляглася, поступившись місцем щастю. I Горобець раптом зрозумів, що був щасливий усе своє життя з моменту народження. Від почуттів, що переповняли його, у нього запаморочилося в голові. Йому здалося, що він знову опинився в затишному гнізді на розкидистому високому дереві, а його турботливі молоді батьки весело щебечуть, радіючи появі свого первістка.

Горобець прийшов до тями. Він лежав на високій подушці та був закутаний безліччю ковдр. Над ним схилилася втомлена Горобчиха; вона сиділа біля нього всю ніч, дбайливо поправляючи ковдри та занепокоєно стежачи за кожним його подихом. Тепер, на світанку, вона задрімала. 3 іншої кімнати чулися тихі голоси дітей. Горобець хотів обережно, щоб не розбудити любу дружину, піднятися, але виявилося, що в нього занадто мало сил. Він подивився у вікно - там було похмуро, по небу дуже повільно пливли важкі хмари. I ось одна з них, не витримавши ваги, зітхнула. I в ту ж саму мить Горобець побачив найперший у цьому році сніг. Сніжинки плавно й нерішуче танцювали в морозному повітрі. Вони гладили найвищі верхівки дерев, зсковзували по застарілим дахам, обережно наближаючись до землі. I, нарешті, 
найперші боязкі сніжинки торкнулися сплячої землі. Вони обережно опускалися на алею, по якій так часто бродили Горобець із Горобчихою, - і алея ставала чистою та блискучою. Горобець посміхнувся спогадам, i, немов відчувши це, Горобчиха розплющила свої втомлені прекрасні очі. Горобці з таким коханням дивилися один на одного, що в кожного перехопило подих від почуттів. Горобчиха непомітно змахнула сльозу й обняла Горобця. Важко сказати, що саме вона ніжно шепотіла йому на вушко, але від цих слів чоловік весь немов сяяв. Раптом забігли діти та внуки - вони, і всі разом, і по черзі, обіймали главу сімейства. А він усе посміхався. Це добре розглянули сніжинки, які пролітали біля вікна. Швидше за все, вони розповіли про це Зимі, яка нечутно влетіла в гніздечко, у кімнату, у якій на ліжку лежав щасливий Горобець. Вона дбайливо поцілувала його та полетіла. Горобець посміхнувся й відчув, що його повіки стають важкими і його хилить на сон. Він заплющив очі та практично відразу чітко побачив дивний і незвичайний сон.

Йому здалося, що він перетворився в білого метелика й тепер кружляє над землею. Він відчув, що може летіти все догори та догори, набагато вище хмар, навіть найвище самої Зими, туди, де розпускаються перші весняні бруньки на небачених деревах. Він уже спрямував туди, але раптом його погляд упав на землю. Далеко внизу він побачив маленьку коричневу грудочку, яка немов притягувала його, наче кликала. Білосніжний метелик почав обережно опускатися все нижче й нижче, доки не досяг найвищих дахів. Тоді він побачив, що там, на припорошеній снігом землі, лежить маленький замерзлий горобчик. Його серце ледь б'ється. Метелик підлетів ближче й обережно сів поруч. Горобчик відкрив очі й посміхнувся. «Ти прилетів до мене, щиро дякую тобі, бо мені так страшно і сумно. Але тепер мене оточує Любов - самотність відступила». А сніг усе падав і падав, укриваючи все навколо блискучим пледом. Білі та пухнасті сніжинки граційно кружляли донизу, а в цей час два білосніжні метелики плавно піднімалися все вище й вище. Вони розповідали сніжинкам про те, як важливо з'явитися на світ, а потім, коли настане час, залишити його в Любові без самотності.

Робота з авторською казкою спрямована на звернення до підсвідомості, вона розкриває внутрішній потенціал клієнта й допомагає йому пережити травмувальні події, сформувати конструктивну модель поведінки і ставлення до себе, світу й оточуючих.

\section{ЛІТЕРАТУРА:}

1. Гнездилов А.В. Авторская сказкотерапия. Дым старинного камина (сказки доктора Балу). Санкт-Петербург : Речь, 2004. С. 4-11.

2. Зинкевич-Евстигнеева Т.Д. Формы и методы работы со сказками. Санкт-Петербург : Речь, 2006. C. 5-135.

3. Соколов Д. Ю. Сказка и сказкотерапия, а еще Лунные дорожки, или приключения принца Эно. 4-е изд., испр. и доп. Москва : Изд-во Института психотерапии, 2005. С. 5-215.

4. Ткач Р.М. Сказкотерапия детских проблем. Санкт-Петербург : Речь ; Москва : Cфрера, 2008. C. 7-11.

5. Черненко М.К. Метод сказкотерапии в работе с детьми и взрослыми : методическое пособие для практикуючих психологов, родителей и педагогов. Одесса : Симекс-принт, 2013. С. 7-26. 